\title{
AN OUTBREAK OF WEST NILE FEVER AMONG MIGRANTS IN KISANGANI, DEMOCRATIC REPUBLIC OF CONGO
}

\author{
YASSIN A. NUR, JAN GROEN, HANS HEUVELMANS, WELMOET TUYNMAN, CEDRICK COPRA, \\ AND ALBERT D. M. E. OSTERHAUS \\ Laboratory of Exotic Viral Infections, Erasmus Medical Center, Rotterdam, The Netherlands; \\ Médecines Sans Frontières (MSF-Holland), Amsterdam, The Netherlands
}

\begin{abstract}
In February 1998, an outbreak of acute febrile illness was reported from the Kapalata military camp in Kisangani, the Democratic Republic of Congo. The illness was characterized by an acute onset of fever associated with severe headache, arthralgia, backache, neurologic signs, abdominal pain, and coughing. In 1 individual, hemorrhagic manifestations were observed. The neurologic signs included an altered level of consciousness, convulsions, and coma. Malaria was initially suspected, but the patients showed negative blood films and failed to respond to antimicrobial drugs. A total of 35 sera collected from the military patients in the acute phase were tested for the presence of $\operatorname{IgM}$ against vector-borne agents. Serum IgM antibodies against West Nile fever virus were found in 23 patients $(66 \%)$, against Chikungunya virus in 12 patients (34\%), against dengue virus in 1 patient (3\%), and against Rickettsia typhi in 1 patient (3\%). All sera were negative for IgM antibody against Rift Valley fever virus, Crimean Congo hemorrhagic fever virus, and Sindbis virus. These data suggest that infections with West Nile fever virus have been the main cause of the outbreak.
\end{abstract}

Infections with arthropod-borne viruses are emerging as a major public health problem in many parts of the world. ${ }^{1,2}$ In sub-Saharan African countries such as in Zaire, ${ }^{3}$ Uganda, ${ }^{4}$ Sudan, ${ }^{5,6}$ and Kenya, ${ }^{7}$ several outbreaks of febrile illness have been associated with arbovirus infections. Both sporadic and major outbreaks of West Nile fever have also been reported in Europe, with the largest in Romania, which had 393 serologically confirmed cases. ${ }^{8}$ In Bucharest alone more than 90,000 residents were infected during this epidemic. The presence of mosquitoes in houses and flooding of basements were identified as risk factors for infection with West Nile virus. ${ }^{9}$ Most recently, an outbreak of Rift Valley fever with a high mortality rate was reported from Somalia, Kenya, and Mauritania involving thousands of humans and animals. ${ }^{10}$ Entomologic studies conducted in large areas of the African continent have identified numerous arthropods that may be involved in the transmission of arboviruses, and virologic investigations have identified more than 40 of the approximately 100 arboviruses that are known to cause human disease to be present in Africa. ${ }^{11,12}$ Despite this knowledge, events that led to the presently observed increase of arbovirus infections in Africa have not been extensively investigated. However simultaneous environmental changes, presence of infected vectors, vector density, increased travel, and presence of non-immune hosts has been considered to be major factors responsible for this increase. ${ }^{13}$ The construction of dams in Egypt and Mauritania, ${ }^{14,15}$ flooding in Somalia, as well as heavy rain falls in several locations have contributed to the increase of breeding sites of several Aedes species in Africa.

In Kisangani, Democratic Republic of Congo, an outbreak of acute febrile illness was recently observed among military personnel recruited from other regions and recently stationed in a nearby military camp. Clinical identification was facilitated by the intensive symptomatology experienced by the military patients (Table 1 ). The aim of the present study was to explore whether an arbovirus infection was involved in this outbreak.
MATERIALS AND METHODS

Study site. The study was conducted in Kisangani, the capital city of Province Oriental in the central/eastern part of Democratic Republic of Congo. Cases were selected from a military camp, Kapalata, situated at the outskirts of the town. The Kapalata camp was reported to contain approximately 2,000 males between 12 and 40 years of age recently recruited from other regions of the country. Comprehensive demographic data were unavailable due to impeded access to the camp. Prior to the febrile illness outbreak, a cholera epidemic in the Kapalata camp was reported to Médecins Sans Frontières (MSF: an international non-governmental organization). This prompted the organization to set up a temporary inpatient department (IPD) facility next to the general hospital to provide care for the large number of patients (approximately 300 at the time) from the Kapalata camp.

Clinical observations. Only patients who developed symptoms while living within the premises of the camp and admitted to the MSF IPD facility were considered as cases. Upon initial examination, patients were found to be febrile (temperature $>38.5^{\circ} \mathrm{C}$ ), acutely ill with neurologic symptoms or in shock, and frequently complaining of headache, arthralgia, abdominal pain, cough, and occasional diarrhea. Virtually all cases were malnourished. Except for 1 case, hemorrhagic manifestations were not observed. Those cases suspected or confirmed for malaria were treated accordingly before a focused investigation was started. An increase in febrile illness was also reported from health centers in $\mathrm{Ki}$ sangani. Thus, additional samples were collected from $\mathrm{Ki}$ sangani residents.

Serum samples. Sera were obtained from 35 acutely ill camp patients admitted to the MSF-IPD facility within 2 weeks after the onset of the symptoms. One patient complying with the case definition (see results) could not be sampled since he died with hemorrhagic symptoms before being sampled. In addition, 10 sera were collected from acutely ill local residents who were seen in several health facilities in 
TABLE 1

Clinical presentation of patients probably involved with the outbreak

\begin{tabular}{lccccr}
\hline & \multicolumn{2}{c}{$\begin{array}{c}\text { Kapalata military } \\
\text { camp }\end{array}$} & & \multicolumn{2}{c}{$\begin{array}{c}\text { Kisangani general } \\
\text { hospital }\end{array}$} \\
\cline { 2 - 3 } \cline { 5 - 6 } \multicolumn{1}{c}{ Symptoms* } & $(\mathrm{n}=35)$ & $(\%)$ & & $(\mathrm{n}=10)$ & $(\%)$ \\
\hline Acute fever & 30 & 86 & & 10 & 100 \\
Headache & 18 & 51 & & 2 & 20 \\
CNS involvement & 16 & 46 & & 0 & 00 \\
Abdominal pain & 15 & 43 & & 6 & 60 \\
Arthralgia & 13 & 37 & & 1 & 10 \\
Respiratory signs & 8 & 23 & & 0 & 0 \\
Convulsions & 4 & 11 & & 0 & 0 \\
\hline
\end{tabular}

$*$ CNS $=$ central nervous system.

Kisangani. These residents included 4 children less than 5 years of age with symptoms similar to those of the camp patients. Samples were sent for analysis to the World Health Organization Reference Center for Arboviruses and Hemorrhagic Fever Viruses in Rotterdam, The Netherlands. The samples were taken at different time points and sent in batches. Two batches of 9 individual serum samples were obtained on February 4 and 6, 1998. Another 2 batches of 9 and 8 serum samples were obtained on February 10 and 26, 1998. The last batch of 10 serum samples was obtained from long-time Kisangani resident patients on March 3, 1998. The time lapse between collection of a sample and analysis varied from 1-2 weeks. Field circumstances did not allow for transport under appropriate temperature conditions. The following viruses were considered as the possible causative agents in the present study: West Nile fever virus, Chikungunya virus, dengue virus, Crimean-Congo hemorrhagic fever virus, Rift Valley fever virus, yellow fever virus, and Sindbis virus. Rickettsia typhi was also considered in the study because of clinical symptoms in combination with the presence of human body lice.

All serum samples were collected after patients were informed that their samples would be used for diagnostic purposes to identify the cause of the apparently circulating disease, and after their informed consent was obtained. This study was approved by the Ethical Committee of the University Hospital Rotterdam.

Detection of IgM antibodies. For the detection of $\operatorname{IgM}$ antibodies against dengue virus (types $1-4$ ), West Nile virus, yellow fever virus, and Sindbis virus, an IgM capture ELISA was used as previously described.6,16,17 IgM antibodies against Rift Valley fever virus, Chikungunya virus, Crimean Congo hemorrhagic fever virus, and $R$. typhi were measured by an indirect immunofluorescence assay as described. ${ }^{18,19}$

Detection of IgG antibodies. For the detection of $\mathrm{IgG}$ antibodies against dengue virus types 1-4 and West Nile virus, an indirect ELISA was used as previously described. ${ }^{16,17}$ Binding of the $\mathrm{IgG}$ antibodies was detected using goat anti-human IgG antibodies labeled with horseradish peroxidase. IgG antibodies against Chikungunya virus, Crimean Congo hemorrhagic fever virus, Sindbis virus, yellow fever virus, Rift Valley fever virus, and $R$. typhi were measured by an indirect immunofluorescence assay as described. ${ }^{18,19}$

Virus isolation. Although the serum samples were not transported under appropriate temperature conditions, an attempt was made to isolate virus from the serum samples using methods available for isolation including mouse and cell culture inoculations. ${ }^{20}$

RESULTS

Clinical findings. The most prominent symptoms of the patients are summarized in Table 1. Acute fever was observed in 30 (86\%) of 35 patients from the Kapalata camp, headache in $18(51 \%)$, central nervous system involvement in $16(46 \%)$, abdominal pain in $15(43 \%)$, arthralgia in $13(37 \%)$, respiratory infection in $8(23 \%)$, and convulsions in $4(11 \%)$. In patients from Kisangani, 10 $(100 \%)$ had acute fever, $6(60 \%)$ had abdominal pain, 2 (20\%) had headache, and $1(10 \%)$ had arthralgia. None of these patients had central nervous system involvement. Based on these findings a case was defined as a patient with acute fever, headache, neurologic symptoms, abdominal pain, and arthralgia. Hemorrhagic manifestations (n $=1)$ and convulsions $(n=4)$ were present in some of the patients. All patients investigated developed symptoms while in the Kapalata camp.

Serum from Kapalata camp patients. Screening of the 35 serum samples collected from acutely ill camp patients showed that $23(66 \%)$ had IgM and IgG antibodies against West Nile fever virus, and 12 (34\%) had $\mathrm{IgM}$ and $\mathrm{IgG}$ antibodies against Chikungunya virus. Only $1(3 \%)$ serum had $\mathrm{IgM}$ and $\mathrm{IgG}$ antibodies against dengue virus, and 1 other (3\%) sample contained IgM and IgG antibodies against $R$. typhi. Three patients showed IgM reactivity against yellow fever virus; however, these patients had a higher reactivity against West Nile fever virus compared with yellow fever virus, indicating that these were probably antibodies with a low degree of cross-reactivity.

Serum from Kisangani residents. Of the 10 patients from the health centers of Kinsingani, IgM and IgG antibodies against dengue virus were found in 3 (30\%), against West Nile fever virus in $1(10 \%)$, against Chikungunya virus 1 (10\%), and against $R$. typhi in 2 (20\%). A high prevalence of IgG antibodies against West Nile fever virus (8 of 10) and Chikungunya virus (6 of 10) was found among the Kisangani patients. In addition, 2 patients had IgG antibodies against Rift Valley fever virus. Overall serologic results are shown in Figure 1 according to the date of sampling.

Virus isolation. Only 17 of 45 samples could be used for virus isolation. Virus was not isolated from any of the samples tested.

\section{DISCUSSION}

Many cases in Africa that present with fever are documented as fever of unknown origin, especially if they fail to respond to antimicrobial drugs. The majority of these conditions remain undiagnosed. However, several arboviruses are frequently considered in the etiology of acute febrile illness. Two main factors known to favor the emergence of vector-borne diseases were present at our study site, which led us to consider a possible role of arbovirus infection in the etiology of this particularly severe febrile illness. First, the outbreak was preceded by heavy rainfall, resulting in flooding in and around the city of Kisangani, providing an ideal breeding site for the vector mosquito (Culex), which 


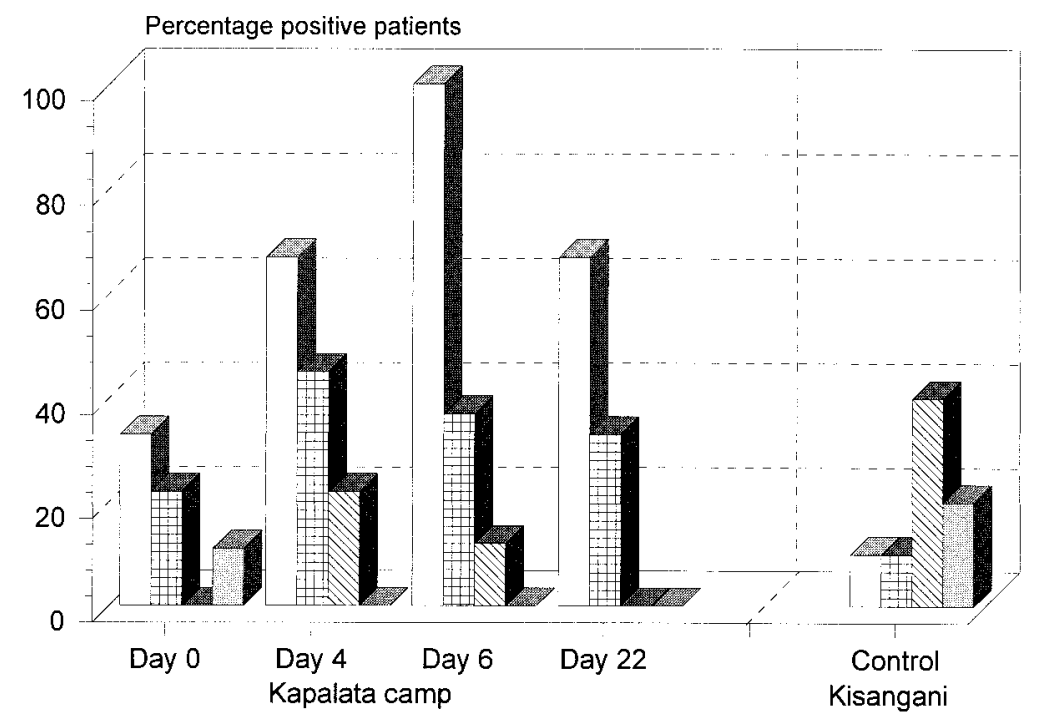

FiguRE 1. IgM and IgG antibodies against West Nile virus (white bars), Chikungunya virus (checkered bars), dengue virus (diagonal bars), and Rickettsia typhi (gray bars) among patients in the Kapalata camp and Kisangani residents.

transmits West Nile virus. Second, the military patients recently recruited were probably from an area nonendemic for West Nile virus and formed a newly introduced pool of susceptible individuals.

In this study, the detection of high titers of $\operatorname{IgM}$ antibody against West Nile virus and the intensity of the clinical symptomatology among patients from the Kapalata camp indicated that these patients had not been previously exposed to this virus. Low-titer IgM antibodies against West Nile virus were detected in only 1 serum sample from a local patient. This sample was also positive for IgM antibodies against dengue virus. Furthermore, the majority ( 9 of 10) of the patients from local areas had high $\mathrm{IgG}$ antibodies titers against West Nile virus, which rules out active West Nile virus transmission and suggests previous exposure to the virus by long-time residents of Kisangani. With the exception of Koutango and Usutu viruses, no extensive studies of other flaviviruses that serologically cross-react with West Nile virus have been reported from this area. However, only 1 case of human infection with Usutu virus has ever been reported from Africa, ${ }^{21}$ and there is no naturally acquired human disease associated with Koutango virus. ${ }^{21}$

We conclude that high titers of IgM antibodies against West Nile virus in $66 \%$ of the febrile camp patients is indicative of active transmission of West Nile virus among these patients. Although confirmation by virus isolation could not be accomplished, our study suggests that West Nile fever virus or an antigenically closely related virus was the main cause of the outbreak of severe febrile illness among the Kapalata camp population in Kisangani, Democratic Republic of Congo.

Authors' addresses: Yassin A. Nur, Jan Groen, Cedrick Copra, and Albert D. M. E. Osterhaus, Laboratory of Exotic Viral Infections, Erasmus Medical Center, Dr. Molewaterplein 40, 3015 GD Rotterdam, The Netherlands. Hans Heuvelmans and Welmoet Tuynman, Médecines Sans Frontières (MSF-Holland), Amsterdam, The Netherlands.

\section{REFERENCES}

1. Robert ES, 1994. The discovery of arbovirus diseases. Ann NY Acad Sci 740: 138-145.

2. Boughton CR, 1994. Arboviruses and disease in Australia. Med J Aust 160: 27-28.

3. Rey JL, Cavallo JD, Milleliri JM, L'Hoest S, Soares JL, Piny N, Coue JC, Jouan A, 1996. Fever of unknown origin (FUO) in the camps of Rwandan refugees in the Coma region in Zaire. Bull Soc Pathol Exot 89: 204-208.

4. Rodhain F, Gonzales JP, Mercier E, Helynck B, Larouze B, Hannoun C, 1989. Arbovirus infections and viral hemorrhagic fevers in Uganda: a serological survey in Karamoja district, 1984. Trans $R$ Soc Trop Med Hyg 83: 851-854.

5. Watts DM, El-Tigani A, Botros BAM, Salib AW, Olson JG, McCarthy M, Ksiazek TG, 1994. Arthropod-borne viral infections associated with a fever outbreak in the northern province of Sudan. J Trop Med Hyg 97: 228-230.

6. McCarthy MC, Haberberger RL, Salib AW, Soliman BA, ElTigani A, Khalid IO, Watts DM, 1996. Evaluation of arthropod-borne viruses and other infectious disease pathogens as the causes of febrile illnesses in the Khartoum province of Sudan. J Med Virol 48: 141-146.

7. Morrill JC, Johnson BK, Hyams C, Okoth F, Tukei PM, Mugambi M, Woody J, 1991. Serological evidence of arboviral infections among humans of coastal Kenya. J Trop Med Hyg 94: 166-168.

8. Tsai TF, Popovici F, Cernescu C, Campbell GL, Nedelcu NI, and the investigative team, 1998. West Nile encephalitis epidemic in southeastern Romaina. Lancet 352: 767-771.

9. Han LL, Popovici F, Alexander JP, Laurentia V, Tengelsen LA, Cernescu C, Gary Jr HE, Ion-Nedelcu N, Campell GL, Tsai TF, 1999. Risk factors for West Nile virus infection and meningoencephalitis, Romania, 1996. J Infect Dis 179: 230-233.

10. Anonymous, 1998. Rift Valley fever-East Africa, 1997-1998. MMWR Morb Mortal Wkly Rep 47: 261-264.

11. Fontenille D, Troare-Lamizane M, Diallo M, Thonnon J, Digoutte JP, Zeller HG, 1998. New vectors of Rift Valley fever in West Africa. Emerg Infect Dis 4: 289-293.

12. Benenson A, ed., 1990. Control of Communicable Diseases in Man. 15th edition. Washington, DC: American Public Health Association, 501-510.

13. Murphy FA, 1998. Emerging zoonoses. Emerg Infect Dis 4. 429-435.

14. Meegan JM, Shope RE, 1981. Emerging concepts on Rift Valley 
fever. Pollard M, ed. Perspectives in Virology. Volume XI. New York. 1981 Alan R. Liss, 267-287.

15. Digoutte JP, Peters CJ, 1989. General aspects of the 1987 Rift Valley fever epidemic in Mauritania. Res Virol 140: 27-30.

16. Besselaar TG, Blackburn NK, Aldridge N, 1989. Comparison of an antibody-capture IgM enzyme-linked immunosorbent assay with IgM indirect immuno-fluorescence for the diagnosis of acute Sindbis and West Nile infections. $J$ Virol Methods 25: 337-345.

17. Schwarz TF, Jager G, Gilch S, Pauli C, 1995. Serosurvey and laboratory diagnosis of imported sandfly fever virus, serotype Toscana, infection in Germany. Epidemiol Infect 114: 501510.

18. Beaty BJ, Calisher CH, Shope RE, 1995. Arboviruses. Lennette
EH, Lennette DA, Lennette ET, eds. Diagnostic Procedures for Viral, Rickettsial, and Chlamydial Infections. Seventh edition. Washington, DC: American Public Health Association, 202-212.

19. Walker DH, Peacock MG 1988. Laboratory diagnosis of rickettsial diseases. Walker DH, ed. Biology of Rickettsial Diseases. Boca Raton, FL: CRC Press, 135-155.

20. Porter KR, Summers PL, Dubois D, Puri B, Nelson W, Henchal E, Oprandy JJ, Hayes CG, 1993. Detection of West Nile virus by the polymerase chain reaction and analysis of nucleotide sequence variation. Am J Trop Med Hyg 48: 440-446.

21. Monath TP, Tsai TF, 1997. Flaviruses. Richman DD, Whitley RJ, Hayden FG, eds. Clinical Virology. New York: ChurchillLivingstone, 1133-1185. 